\title{
Somatostatin in the human heart and comparison with guinea pig and rat heart
}

\author{
S M DAY,^ J GU,† J M POLAK,† S R BLOOM* \\ From the Departments of ${ }^{\star}$ Medicine and $\dagger$ Histochemistry, Royal Postgraduate Medical School, London
}

SUMMARY Somatostatin has been shown to have negative inotropic and chronotopic effects and to restore sinus rhythm in some cases of cardiac arrhythmia. Using acid extracts, regions of human heart were examined by radioimmunoassay to determine their somatostatin content. Mean (SD) concentrations of $4.1(0.8) \mathrm{pmol} / \mathrm{g}$ and $2.9(0.8) \mathrm{pmol} / \mathrm{g}$ were found in atrioventricular node and right atria respectively and were significantly higher than in other heart regions. Using fresh heart tissue from guinea pigs, somatostatin was localised to cardiac nerves by immunocytochemistry. Nerves containing somatostatin were most abundant in the atria, where the concentrations measured by radioimmunoassay were $7.6(1.0)$ and $2.6(0.4) \mathrm{pmol} / \mathrm{g}$ for right and left atria respectively.

Somatostatin contained in cardiac nerves may have a physiological role in the cardiac conduction system.

Somatostatin was first isolated as a 14 amino acid peptide from ovine hypothalami ${ }^{1}$ and subsequently found also to exist in a 28 amino acid form. ${ }^{2}$ It is present in peripheral sympathetic and sensory nerves in mammals. ${ }^{3}$ Although there has been no previous report of its presence in mammalian heart, infusion at pharmacological doses in man causes bradycardia and a fall in cardiac output, ${ }^{4-6}$ and restores sinus rhythm in cases of paroxysmal supraventricular and junctional tachycardia. ${ }^{7}$ We now report that somatostatin is present in the normal human heart, particularly in the right atrium and atrioventricular node, and that in fresh guinea pig heart it can be localised to the neural tissue. Somatostatin endogenous to the heart may therefore play a local role in the conduction system. Nevertheless, a study of the distribution of somatostatin in guinea pig and rat heart showed wide species variation in distribution and molecular form, making it unlikely that either species could serve as a good model for the study of human cardiac somatostatin.

\section{Materials and methods}

TISSUE EXTRACTION

Specific regions were dissected from fresh normal postmorten human $(n=7)$, guinea pig $(n=5)$, and rat

Requests for reprints to Professor S R Bloom, Department of Medicine, Hammersmith Hospital, Du Cane Road, London W12 OHS.

Accepted for publication 25 September 1984 $(n=6)$ hearts and either frozen rapidly on dry ice and stored at $-70^{\circ} \mathrm{C}$ until extraction (human) or extracted immediately (guinea pig and rat). In guinea pig and rat, because of the small size of the atrioventricular node a small region of septum containing the node was extracted whole. In the rat, left and right atria were extracted together. Somatostatin was extracted by plunging diced tissue into boiling acetic acid ( 0.5 mmol) and maintaining it at $100{ }^{\circ} \mathrm{C}$ for 10 minutes.

\section{RADIOIMMUNOASSAY}

Duplicate $20 \mu \mathrm{l}$ aliquots of the extract were assayed for somatostatin by a sensitive and specific radioimmunoassay, which has been previously described, ${ }^{8}$ using an antibody which cross reacts fully with both the 14 and 28 amino acid forms of somatostatin.

\section{CHARACTERISATION OF MOLECULAR FORMS}

Analysis of the molecular forms of the immunoreactive somatostatin in human atrioventricular node was carried out by gel permeation chromatography using Sephadex G50 gel.

\section{IMMUNOCYTOCHEMISTRY}

Whole hearts of adult guinea pigs $(n=6$, body weight $200-300 \mathrm{~g}$ ) were removed and promptly fixed in $0.4 \%$ benzoquinone ${ }^{9}$ made up in phosphate buffered saline (PBS pH 7.2) for three hours at room temperature. After being washed overnight in PBS containing 15\% sucrose, the tissues were snap frozen for cryostat blocks. Sections were cut at a thickness of $8 \mu \mathrm{m}$ and 
Table Preabsorption test of antisera for immunocytochemistry

\begin{tabular}{lll}
\hline Antisera to & Antigens & Results \\
\hline $\begin{array}{l}\text { Somatostatin 28 (4-14) } \\
\text { Somatostatin 28 (4-14) }\end{array}$ & $\begin{array}{l}\text { Somatostatin 28 (4-14) } \\
(10 \mathrm{nmol} / \mathrm{ml})\end{array}$ & $\begin{array}{l}\text { Positive } \\
\text { Negative }\end{array}$ \\
Somatostatin 28 (4-14) & $\begin{array}{c}\text { Somatostatin 14 } \\
(20 \mathrm{nmol} / \mathrm{ml})\end{array}$ & Positive \\
Somatostatin 14 & $\begin{array}{c}\text { Negative } \\
\text { Somatostatin 14 }\end{array}$ & $\begin{array}{c}\text { Somatostatin 14 } \\
(20 \mathrm{nmol} / \mathrm{ml})\end{array}$ \\
Somatostatin 14 & $\begin{array}{c}\text { Somatostatin 28 (4-14) } \\
(10 \mathrm{nmol} / \mathrm{ml})\end{array}$ & Negative \\
\hline
\end{tabular}

*nmol antigen/ml of diluted antiserum.

tWithout preabsorption with antigen.

Positive, certain nerves were positively immunostained; Negative, no nerves were immunostained.

mounted on poly-L-lysine coated glass slides. ${ }^{10} \mathrm{~A}$ modified indirect immunofluorescence method ${ }^{11}$ was carried out.

Antisera to somatostatin 14 and to somatostatin 28 were used; these had been raised in New Zealand white rabbits to somatostatin 14 and 4-14 fragment of somatostatin 28 respectively, which had been conjugated to keyhole limpet haemocyanin by glutaraldehyde.

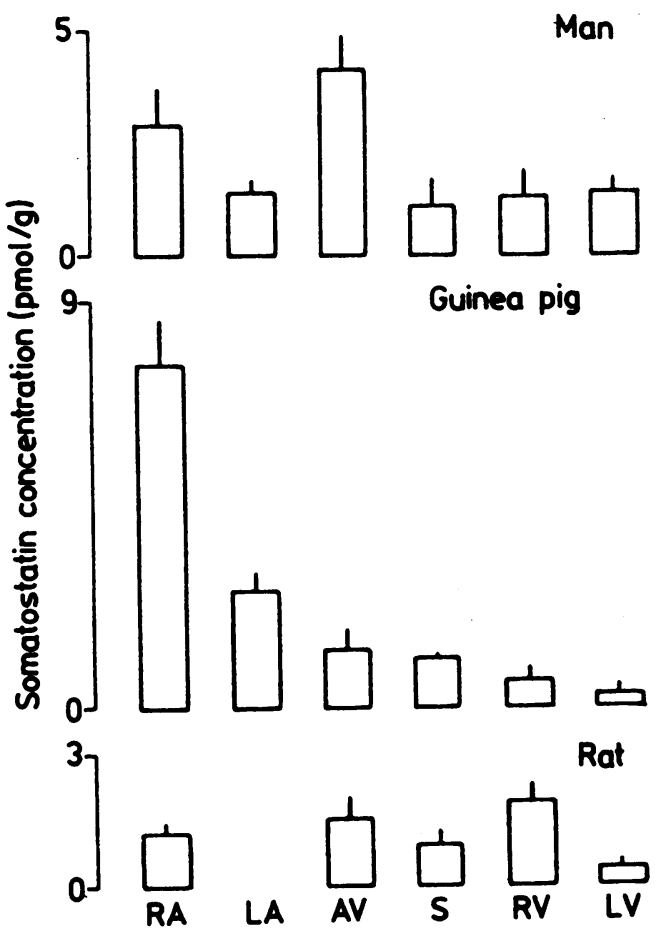

Fig. 1 Mean (SEM) tissue concentrations of somatostatin in heart regions of man, guinea pig, and rat (pmol/g wet weight). $R A$, right atrium; $L A$, left atrium; $A V$, atrioventricular node; $S$, septum; $R V$, right ventricle; $L V$, left ventricle.
The controls for immunocytochemistry included preabsorption of the antisera with corresponding antigens, use of normal rabbit serum as the first layer, and omission of the first layer. In addition, the antiserum to somatostatin 14 was preincubated with somatostatin 28 (fragment 4-14) and that to somatostatin 28 (fragment 4-14) with somatostatin 14 in order to check the cross reactivity of the two antisera (Table). The Table gives the characteristics of the antisera.

\section{Results}

Figure 1 shows the concentrations of somatostatin in the dissected tissues. In man the highest concentrations of somatostatin were found in the atrioventricular node and right atrium ( $p<0.05$ compared with the septum and ventricle wall, Student's paired $t$ test), although there were appreciable concentrations in all regions. In the guinea pig the distribution showed some similarity to that in man, with the highest concentration in the right atrium $(p<0.01$ compared with all other regions). The method of dissection of the atrioventricular node in the guinea pig may have obscured a higher concentration of somatostatin in this region; nevertheless, it was higher than in the ventricular walls $(p<0.01)$. In contrast to human and guinea pig heart, the somatostatin concentrations in rat heart regions were generally lower and the distribution was more uniform. Analysis of the molecular form of the immunoreactive somatostatin in the human heart showed it to elute in a single peak, corresponding to synthetic somatostatin 14 (Fig. 2).

Several nerve fibres in the guinea pig heart were found to be immunoreactive to the antiserum against somatostatin 28 (4-14 fragment), and no immunoreactivity was detected using antiserum to somatostatin 14. There were more nerve fibres immunoreactive to somatostatin in the atria than in the ventricles. These immunoreactive nerves were mainly associated with cardiac muscle (Fig. 3) and occasionally with coronary blood vessels (Fig. 4). They were slightly more frequent in the regions of the sinoatrial and the atrioventricular nodes than in other areas. The positive immunostaining could be quenched by somatostatin 28 (4-14 fragment) but not by somatostatin 14 (Table).

\section{Discussion}

High somatostatin concentrations are found in human heart tissue in the regions containing specialised pacemaker and conducting cells. Infusions of somatostatin in man cause bradycardia and a fall in cardiac output, ${ }^{4-6}$ but the concentrations of somatostatin achieved during the infusions are much higher 


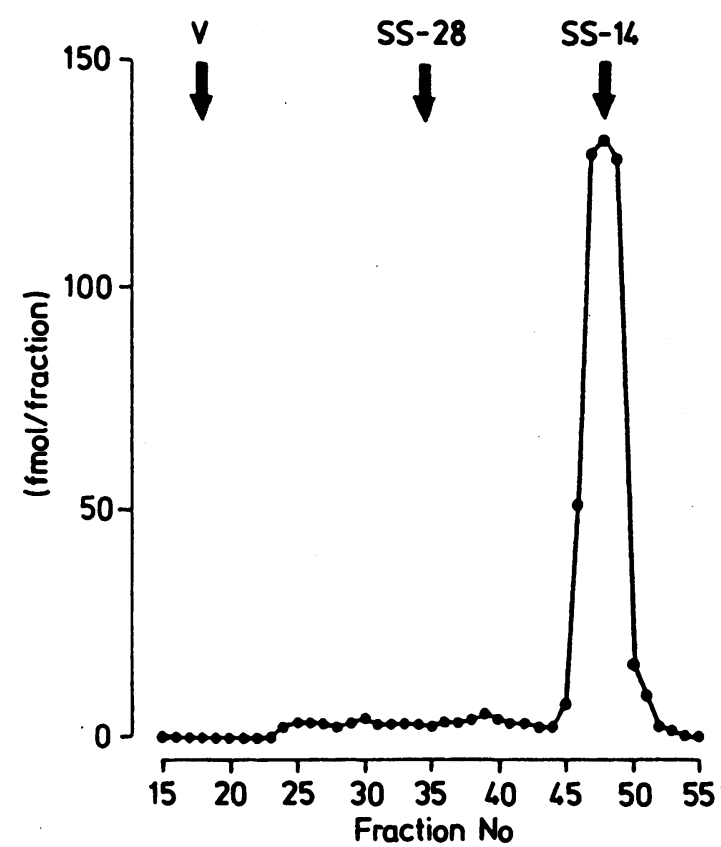

Fig. 2 Sephadex $G 50$ elution profile of somatostatin immunoreactivity from pooled human atrioventricular node extracts. SS, somatostatin; $V$, void volume. than those found in the peripheral circulation under physiological conditions. It is, therefore, improbable that circulating somatostatin normally affects cardiac function, but endogenous cardiac nerve containing somatostatin could allow an effective concentration to be achieved by local release.

In common with the pattern of tissue distribution between the species, the pharmacological effects of somatostatin on guinea pig but not rat heart ${ }^{12}$ are similar to those on human heart. In guinea pigs, somatostatin causes bradycardia and a fall in cardiac output in vivo ${ }^{13}$ and exerts a negative inotropic effect on perfused isolated atria. ${ }^{12}$

Other cardiac regulatory peptides-in particular neuropeptide tyrosine-have been found in human cardiac nerves. 1415 Somatostatin is clearly shown to be contained in nerves in the guinea pig heart, but no fresh human heart was available for examination, and staining of postmortem tissue from peripheral organs with antisera for this peptide is unreliable. It is likely, but not yet proved, therefore, that human cardiac somatostatin is contained in cardiac innervation. Somatostatin has been found in other peripheral tissues in sympathetic and sensory fibres, ${ }^{3}$ but the possibility that it may exist in parasympathetic fibres in the heart must be considered, in view of its functional effects and its location in vagal fibres in the heart of the toad. ${ }^{16}$ The somatostatin immunoreactive nerves in guinea pig heart are mainly associated with cardiac

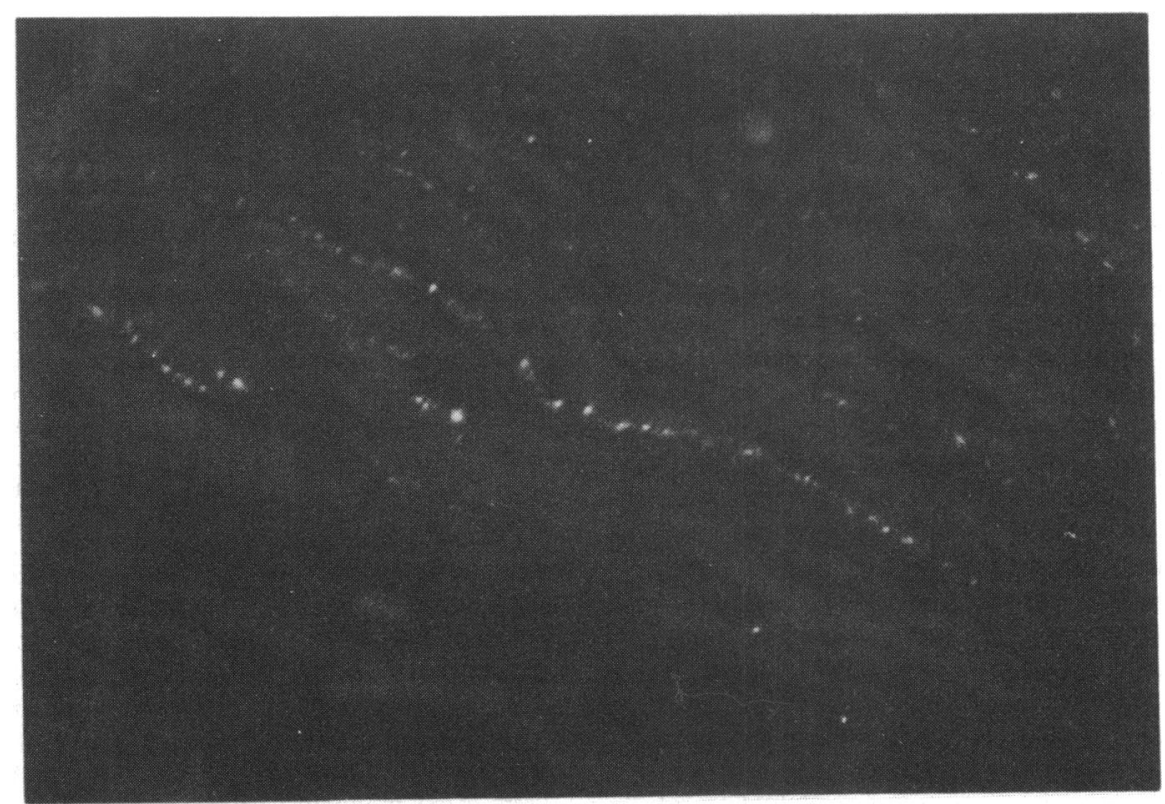

Fig. 3 Nerves immunoreactive to somatostatin in the cardiac muscle of the left atrium of guinea pig ( $\times 450)$. 


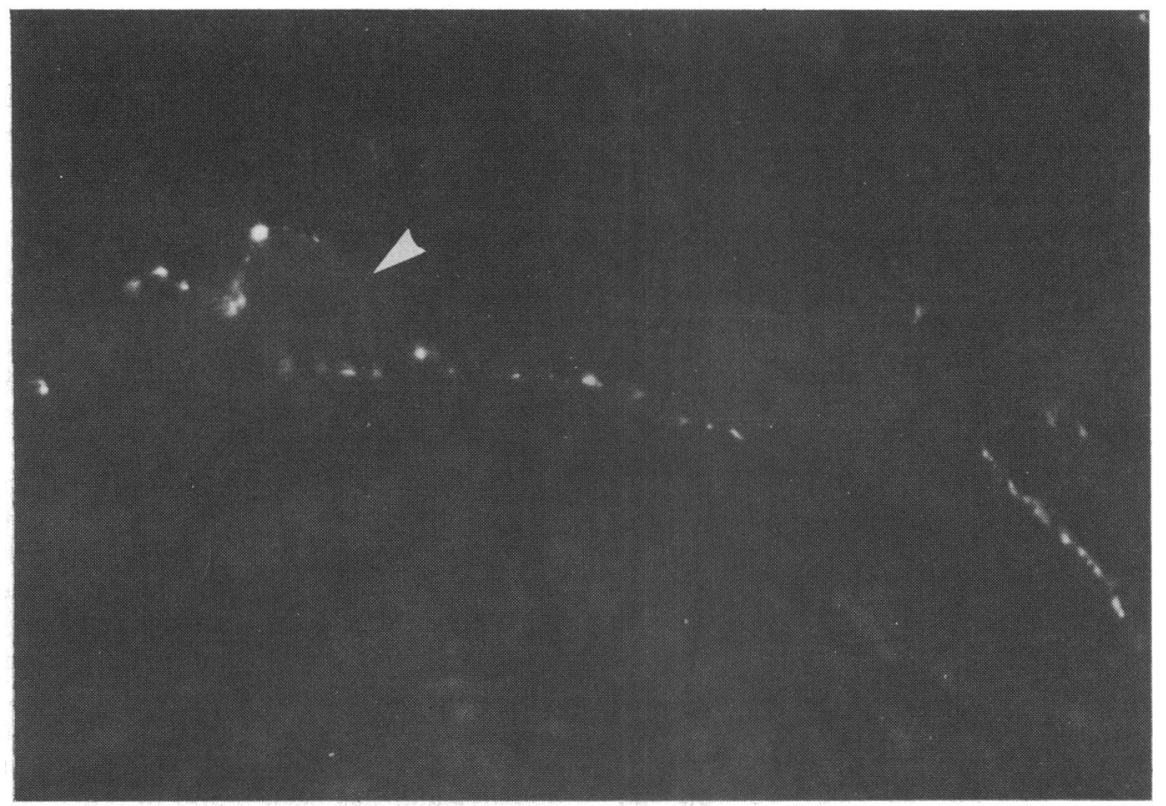

Fig. 4 Nerves immunoreactive to somatostatin associated with an arteriole (arrow) in the left ventricular myocardium of guinea pig $(\times 400)$.

muscle, whereas neuropeptide tyrosine immunoreactive nerves are closely associated with the coronary vasculature in addition to muscle. ${ }^{17}$ This implies a possible functional differentiation with cardiac somatostatin acting directly on cardiac tissue rather than on coronary blood flow.

The mode of action of somatostatin at the cellular level is not understood, but there is evidence that it decreases the calcium ion flux into the cell-that is, it acts as a slow channel blocker. The negative inotropic effect of somatostatin on isolated guinea pig atria can be abolished by raising the calcium ion concentration in the perfusing medium. ${ }^{12}$ The pacemaker cells of the sinoatrial node and automatic cells in the proximal regions of the atrioventricular node are activated largely by the slow inward current, which may also be observed in other cardiac cells under abnormal conditions. The effect of calcium channel blockers (for example, verapamil) on atrioventricular conduction is of clinical importance in that it provides a mechanism whereby nodal re-entrant supraventricular tachycardia can be abolished and the ventricular response in atrial flutter and fibrillation can be controlled. ${ }^{18}$ This may be the mechanism by which intravenously administered somatostatin corrects paroxysmal supraventricular and junctional tachycardia in man. ${ }^{6}$ Long and short acting potent analogues of somatostatin are now available and are, therefore, potential new therapeutic agents in cardiac arrhythmias. Further study of somatostatin endogenous to the heart may provide a rational basis for their use.

We thank the British Heart Foundation and Tobacco Advisory Council for support.

\section{References}

1 Brazeau P, Vale W, Burgus R, et al. Hypothalamic polypeptide that inhibits the secretion of immunoreactive pituitary growth hormone. Science 1973; 179: 77-9.

2 Pradayrol L, Jörnvall H, Mutt V, Ribet A. N-terminally extended somatostatin: the primary structure of somatostatin-28. FEBS Lett 1980; 109: 55-8.

3 Hokfelt T, Johansson O, Ljungdahl A, Lundberg JM, Schultzberg M. Peptidergic neurones. Nature 1980; 284: 515-21.

4 Chernish SM, Miller RE, Rosenak BD, Brunelle RL. The effect of D-val ${ }^{1}$, D-Tryp ${ }^{8}$, somatostatin on the hematopoetic, cardiovascular systems and gastrointestinal tract [Abstract]. Gastroenterology 1979; 76: 1113.

5 Hallemans R, Naeije R, Melot C, Mols P, Reding R. Systemic and pulmonary haemodynamic effects of somatostatin [Letter]. Lancet 1981; i: 1270.

6 Rosenthal J, Raptis S, Zoupas C, Escobar-Jimenez F. Inhibition by somatostatin of renin, blood pressure, and cardiac and stroke index in essential hypertension. Circ Res 1978; 43 (suppl 1): 69-76.

7 Greco A, Ghirlanda G, Barone C, et al. Somatostatin in paroxysmal supraventricular and junctional tachycardia. 
Br Med F 1984; 288: 28.

8 O'Shaugnessy DJ. Somatostatin. In: Bloom SR, Long RG, eds. Radioimmunoassay of gut regulatory peptides. London: WB Saunders, 1982: 138-45.

9 Bishop AE, Polak JM, Bloom SR, Pearse AGE. A new universal technique for the immunocytochemical localization of peptidergic innervation [Abstract]. $\mathcal{F}$ Endocrinol 1978; 77: 25P-6P.

10 Huang WM, Gibson SJ, Facer P, Gu J, Polak JM. Improved section adhesion for immunocytochemistry using high molecular weight polymers of L-lysine as a slide coating. Histochemistry 1983; 77: 275-9.

$11 \mathrm{Gu} \mathrm{J}$, Islam KN, Polak JM. Repeated application of first-layer antiserum improves immunofluorescence staining: a modification of the indirect immunofluorescence staining procedure. Histochem $f$ 1983; 15: 475-82.

12 Quirion R, Regoli D, Rioux F, St-Pierre S. An analysis of the negative inotropic action of somatostatin. $\mathrm{Br} \mathbf{f}$ Pharmacol 1979; 66: 251-7.

13 Rioux F, Kérouac R, St-Pierre S. Somatostatin: interac- tion with the sympathetic nervous system in guinea pigs. Neuropeptides 1981; 1: 319-27.

14 Forssmann WG, Reinecke $M$, Weihe E. Cardiac innervation. In: Bloom SR, Polak JM, Lindenlaub E, eds. Systemic role of regulatory peptides. Stuttgart: FK Schuttauer Verlag 1982; 18: 329-49.

15 Gu J, Polak JM, Adrian TE, Allen JM, Tatemoto K, Bloom SR. Neuropeptide tyrosine (NPY)-a major cardiac neuropeptide. Lancet 1983; i: 1008-10.

16 Campbell G, Gibbins IL, Morris JL, et al. Somatostatin is contained in and released from cholinergic nerves in the heart of the toad Bufo marinus. Neuroscience 1982; 7: 2013-23.

$17 \mathrm{Gu} \mathrm{J}$, Polak JM, Allen JM, et al. High concentrations of a novel peptide, neuropeptide $Y$, in the innervation of mouse and rat heart. $\mathcal{F}$ Histochem Cytochem 1984; 32: 467-72.

18 Schamroth L, Krikler DM, Garrett C. Immediate effects of intravenous verapamil in cardiac arrhythmias. $\mathrm{Br} \mathrm{Med}$ f 1972; i: 660-2. 